\title{
Correction to: Manuel d'échographie en anesthésie-réanimation et médecine péri-opératoire
}

\section{Collège national des enseignants d'anesthésie et de réanimation. Presses Universitaires} François-Rabelais, 2021; 289 pages. ISBN 9782869067585

\author{
Stéphane Coutu, MD
}

Published online: 13 September 2021

(C) Canadian Anesthesiologists' Society 2021

Correction to: Can J Anesth/J Can Anesth (2021) 68:1302-1303 https://doi.org/10.1007/s12630-021-02017-y

This book review written by Stéphane Coutu, was originally published online on the publisher's internet portal on June 7, 2021 with Open Access under a Creative Commons Attribution (CC BY) license 4.0. With the author's/authors' decision to cancel Open Access the copyright of the article changed on September 2, 2021 to (c) Canadian Anesthesiologists' Society 2021 with all rights reserved.

Publisher's Note Springer Nature remains neutral with regard to jurisdictional claims in published maps and institutional affiliations.

The original article can be found online at https://doi.org/10.1007/ s12630-021-02017-y.

S. Coutu, MD $(\bowtie)$

Centre Hospitalier Universitaire de Sherbrooke, Sherbrooke, QC,

Canada

e-mail: stephcoutu@videotron.ca 